\title{
Tadeusz Marszał, Szadkowski słownik biograficzny. Średniowiecze i renesans, Wydawnictwo Uniwersytetu Łódzkiego, Łódź 2012, ss. 188
}

(c) (1) $\Theta$ DOI: http://dx.doi.org/10.12775/KLIO.2014.011

W ydawanie słowników biograficznych to niewątpliwie pożyteczna inicjatywa. W ostatnich latach na rynku wydawniczym pojawiło się wiele takich pozycji, w tym także te poświęcone miastom. Obok kilkutomowych wydawnictw przedstawiających biogramy wybitnych osobistości większych miast, takich jak Bydgoszcz, Toruń czy Włocławek², opracowań słownikowych doczekały się też miasta mniejsze, takie jak np. Wieluń czy Dobrzyń ${ }^{3}$. Recenzowana praca wpisuje się niewątpliwie $\mathrm{w}$ ten nurt.

Szadkowski stownik biograficzny nie jest jak większość tego typu wydawnictw dziełem zbiorowym. Ma on tylko jednego autora i nie jest nim w dodatku zawodowy historyk. Tadeusz Marszał, który podjął się próby opracowania biogramów znamienitych przedstawicieli Szadku doby średniowiecza i czasów wczesnonowożytnych (faktycznie z okresu od początku XV do początku XVII wieku) jest bowiem geografem, profesorem Uniwersytetu Łódzkiego, który ma jednak w swoim dorobku kilka publikacji z zakresu historii, w tym wydaną w 1995 r. monografię miasta.

Książka, poza wstępem, podzielona jest na pięć rozdziałów, a całość kończy słownik pojęć i terminów używanych w XIV-XVI wieku, wykaz literatury i streszczenie $\mathrm{w}$ języku angielskim. W rozdziale pierwszym

2 Zob.: Bydgoski stownik biograficzny, red. Janusz Kutta, t. 1-6, Bydgoszcz 1994-2000; Torunski stownik biograficzny, red. Krzysztof Mikulski, t. 1-6, Toruń 1998-2010; Wtoctawski stownik biograficzny, red. Stanisław Kunikowski, t. 1-6, Włocławek 2004-2011 .

3 Wieluński stownik biograficzny, red. Zbigniew Szczerbik, Zdzisław Włodarczyk, t. 1, Wieluń 2012; M. Krajewski, Dobrzyński stownik biograficzny. Ludzie europejskiego regionu, Włocławek 2002. 
(s. 9-22) T. Marszał podjął próbę przedstawienia społeczności Szadku w XV-XVI wieku. Rozdział drugi (s. 23-54) zawiera różnej objętości biogramy 21 wybitnych szadkowian doby średniowiecza i renesansu, które ułożone zostały w porządku chronologicznym. Trzy następne rozdziały poświęcone zostały kolejnym trzem wybitnym szadkowianom. W rozdziale trzecim (s. 55-88) przybliżona została postać XV-wiecznego prawnika i dyplomaty Jakuba z Szadka, w czwartym (s. 89-134) astrologa, historyka nauki i bibliofila Mikołaja Prokopowicza z Szadka, natomiast bohaterem piątego rozdziału (s. 135-156) został śpiewak i kompozytor Tomasz Szadek. Wyniki badań na tymi trzema postaciami T. Marszał publikował już wcześniej w latach 2002-20094.

Książka T. Marszała nie jest wolna od błędów. W rozdziale pierwszym (s. 13, przypis 19) autor informuje, że

Już w XIV w. w Szadku były osoby posiadające pewne wykształcenie, o czym świadczy np. zachowany w rękopisie w Bibliotece Kórnickiej wykaz świadków (i ich zeznań, 126 osób) w toczonym w 1339 r. w Warszawie sporze z zakonem krzyżackim, wśród których znajdują się osoby z Szadku [...].

Odwoływanie się do rękopisu z Kórnika nie wydaje się jednak w tym przypadku konieczne. Dokumenty procesu z 1339 r. zostały bowiem wydane jeszcze w XIX wieku drukiem5. Dodajmy także, że szadkowianie, którzy złożyli zeznania podczas procesu zostali już w literaturze dostrzeżeni ${ }^{6}$. Dyskusyjne wydaje się poza tym zaliczenie wszystkich przedstawicieli Szadka zeznających w procesie do grona osób wykształconych. Jako

4 Zob.: T. Marszał, Tomasz Szadek - kompozytor, śpiewak, ksiadz, „Biuletyn Szadkowski” 2002, t. 2, s. 7-26; idem, Jakub z Szadka - ksiądz, dyplomata i prawnik, „Biuletyn Szadkowski” 2008, t. 8, s. 5-30; idem, Mikotaj Prokopowicz z Szadka-astrolog, astronom, historyk nauki, mitośnik i znawca książek, „Biuletyn Szadkowski” 2009, t. 9, s. $5-36$.

${ }^{5}$ Lites ac res geste inter Polonos Ordinemque Cruciferorum (dalej: Lites), t. 1 (wyd. 2), ed. I. Zakrzewski, Poznań 1890.

${ }^{6}$ Zob.: W. Sieradzan, Świadomość historyczna świadków w procesach polsko-krzyżackich w XIV i XV wieku, Toruń 1993, s. 173-174, 179-180, 194, 216, 222. 
litteratus wymieniony został wszak tylko Gocwin Rykalicz' Wobec braku odpowiednich źródeł trudno do tego grona zaliczyć pozostałych ${ }^{8}$.

W tym samym rozdziale (s. 19-21), T. Marszał zestawił w tabeli studentów z Szadku i okolic, którzy zapisali się do wszechnicy krakowskiej w XV wieku. Autor opracował ją na podstawie wydanego w latach siedemdziesiątych XX wieku indeksu studentów Uniwersytetu Krakowskiego z XV wieku'. Nie znał niestety wydanej w 2004 roku metryki Uniwersytetu w Krakowie ${ }^{10}$, która to właśnie powinna stanowić podstawę jego dociekań. T. Marszał w swym zestawieniu pominął pięciu szadkowian, choć do uniknięcia przynajmniej niektórych błędów wystarczyłaby uważna lektura indeksu studentów, na podstawie którego autor zdecydował się opracować tabelę. Pominięci szadkowianie zapisani na Uniwersytet w Krakowie to: odnotowany w 1408 roku „Stanislaus Martini de Szadek”"11, w 1413 roku „Nicolaus Blasii de Szadek”12, w 1435 roku „Laurencius Andree de Szadek”13, w 1438 roku „Paulus de Szadeck”14 i w 1460 roku „Nicolaus Laurencii de Szadecz" ${ }^{15}$.

7 Zob.: Lites, s. 270. Na jego temat zob. też: J. Bieniak, „Litterati” świeccy w procesie warszawskim z 1339 roku, [w:] Cultus et cognito. Studia z dziejów średniowiecznej kultury, Warszawa 1976, s. 97-106, tu: s. 105.

${ }^{8}$ Mowa tu o krawcu Arnaldzie (zob. W. Sieradzan, op. cit., s. 173-174, nr 7), mieszczanach: Franciszku (ibidem, s. 179, nr 27), Kuncze Kitelu (ibidem, s. 194, nr 87) i sołtysie z Wilamowa (również mieszczaninie) Zolmanie (ibidem, s. 222, nr 199) oraz plebanie Wacławie (ibidem, s. 216, nr 175).

9 Indeks studentów Uniwersytetu Krakowskiego 1400-1500, oprac. J. Zathey, J. Reichan, Wrocław-Warszawa-Kraków-Gdańsk 1974.

${ }^{10}$ Metryka Uniwersytetu Krakowskiego z lat 1400-1508, t. I-II, wyd. A. Gąsiorowski, T. Jurek, I. Skierska przy współpracy R. Grzesika, Kraków 2004.

11 Ibidem, s. 66;

12 Metryka..., s. 79; Indeks..., s. 212 - tu nieprawidłowo odczytane miasto (Szandec).

13 Metryka..., s. 171; Indeks..., s. 163. T. Marszał niesłusznie uznał, że zapisał się na uniwersytet w $1436 \mathrm{r}$.

${ }^{14}$ Metryka..., s. 183; Indeks..., s. 243. Określony został w metryce jako confessor regis, plebanus in Prosowic; szerzej o nim zob.: U. Borkowska, Królewscy spowiednicy, [w:] Ludzie, Kościót, wierzenia. Studia z dziejów kultury i spoteczeństwa Europy Środkowej ('sredniowiecze - wczesna epoka nowożytna), red. W. Iwańczak, S. K. Kuczyński, Warszawa 2001, s. 187, nr 11. Mimo że T. Marszał nie znał tych prac, skreślił na kolejnych stronach (s. 42) jego biogram.

15 Metryka..., s. 284; Indeks..., s. 221. 
Kilku uzupełnień wymagają też biogramy zamieszczone w rozdziale drugim. T. Marszał, przedstawiając sylwetkę Stanisława Piórko z Szadka, syna Piotra (s. 26-27), pominął szereg źródeł proweniencji papieskiej publikowanych w Bullarium Poloniae. W biogramie duchownego autor podaje, że Stanisław z Szadka w latach 1403-1405 był wikariuszem katedralnym w Gnieźnie. W świetle dostępnych źródel jego obecność w charakterze wikariusza przy katedrze gnieźnieńskiej możemy wydłużyć aż do $1411 \mathrm{roku}^{16}$. Dzięki źródłom z tego tylko wydawnictwa wiemy również, że osiągnął, bądź starał się o szereg kolejnych beneficjów: plebana „in Rzeszotharzewo (Resotarzewo, Rzesotarzewo)" w diecezji gnieźnieńskiej, kanonika gnieźnieńskiego, poznańskiego i krakowskiego oraz plebana w Spicymierzu (lata 1411-1425). Starał się objąć lub osiagnął jeszcze kolejne beneficja: notariusza, wówczas jeszcze elekta poznańskiego Andrzeja Łaskarzyca z Gosławic, kanonika i prepozyta uniejowskiego, archidiakona i kustosza poznańskiego oraz kustosza gnieźnieńskiego ${ }^{17}$. T. Marszał z przywołanych wyżej informacji wiedział jedynie o posiadanych kanoniach w Krakowie, Poznaniu i Gnieźnie, choć i te informacje nie były pełne. Wątpliwa wydaje się również data śmierci Stanisława podana przez T. Marszała (1430). Duchowny zmarł bowiem najpewniej między 11 lipca 1425 a 1 grudnia 1426 roku$^{18}$. Szczegółowe zbadanie kariery Stanisława to ważne zadanie dla następnych badaczy, mimo że biogram duchownego, niestety nie bez luk, kilka lat temu opracowała już Anna Jabłońska ${ }^{19}$. Pracy tej T. Marszał niestety nie znał. Autor Stownika nie uwzględnił również książki Ireny SułkowskiejKuraś o dokumentach królewskich w latach 1370-1444. Znajomość jej treści pomogłaby autorowi w pełniejszym opisaniu działalności Mikołaja Bruchrinka (s. 29-30) ${ }^{20}$. Nie możemy poza tym wykluczyć, że Jan z Szadka (s. 31-35), kolejny z bohaterów drugiego rozdziału pracy T. Marszała, jest

${ }^{16}$ Bullarium Poloniae, t. 3: 1378-1417, ed. I. Sułkowska-Kuraś, S. Kuraś, RzymLublin 1988, nr 1318.

${ }_{17}$ Zob.: ibidem, indeks, s. 294; t. 4 1417-1431, ed. I. Sułkowska-Kuraś, S. Kuraś, H. Wajs, Rzym-Lublin 1992, indeks, s. 565.

${ }^{18}$ A. Jabłońska, Kapituła uniejowska do poczattu XVI wieku, Kielce 2005, s. 114.

${ }^{19}$ Ibidem, s. 113-114.

${ }^{20}$ Zob.: I. Sułkowska-Kuraś, Dokumenty królewskie i ich funkcja w pañstwie polskim za Andegawenów i pierwszych Jagiellonów 1370-1444, Warszawa 1977, s. 202, nr 15. 
tożsamy ze zmarłym przed 7 lutego 1465 r. Janem, plebanem w Obrazowie, kanonikiem i oficjatem sandomierskim, sędzią in spiritualibus sandomierskim oraz kanonikiem kieleckim ${ }^{21}$.

W biogramie Gabriela z Szadka, syna Feliksa (s. 48-52) nie do końca precyzyjne są dane dotyczące jego aktywności w poznańskiej kapitule katedralnej. Brakuje tu przede wszystkim odwołania się do badań Konrada Lutyńskiego, który szczegółowo przyjrzał się XVI-wiecznym dziejom korporacji $^{22}$. Z pracy tej dowiadujemy się bowiem, że Gabriel z Szadka posiadał kanonię fundi Jankowo w latach 1571-158423. Wiemy również, że w 1571 r. w momencie instalacji Gabriela na kanonię poznańską został on zwolniony z opłaty pro iucundo ingressu, co tłumaczono kosztami, jakie Gabriel poniósł w związku z przeprowadzką z Krakowa do Poznania ${ }^{24}$. Dodajmy również, że w 1580 r. Gabriel z Szadka odnotowany został jeszcze jako trybunalista (sędzia) ${ }^{25}$.

Cały rozdział trzeci (s. 55-88) T. Marszał poświęcił osobie dyplomaty i prawnika Jakuba z Szadka. Szkoda, że autor nie wykorzystał najnowszych ustaleń Leszka Poniewozika, który badał karierę Jakuba w związku z pracami nad składem osobowym średniowiecznej kolegiaty sandomierskiej ${ }^{26}$. Znajomość tej pracy pozwoliłaby uzupełnić biogram Jakuba. Dzięki badaniom L. Poniewozika wiemy bowiem, że krewniakami Jakuba byli bliżej nie znani Mikołaj Swlek i Alber. T. Marszał nie wspomina również, że Jakub z Szadka w 1436 roku odnotowany został jako rektor szkoły kolegiackiej w Sandomierzu, a także, że w 1472 roku spierał się o kanonię uniejowską. Mało precyzyjnie, w odróżnieniu od wyników L. Poniewozika, zakreślał autor również ramy chronologiczne obejmowanych przez Jakuba godności kościelnych ${ }^{27}$.

${ }^{21}$ Por.: L. Poniewozik, Prataci i kanonicy sandomierscy $w$ okresie średniowiecza, Toruń 2004, s. 197-198, nr 64.

${ }^{22}$ K. Lutyński, Kapituła katedralna w Poznaniu w XVI wieku. Organizacja i majątek, Poznań 2000.

23 Ibidem, s. 74.

${ }^{24}$ Ibidem, s. 100, przypis 382.

25 Ibidem, s. 120.

${ }^{26}$ L. Poniewozik, op. cit., s. 193-195, nr 56.

27 Ibidem. 
Ostatnią uwagą jest niezbyt fortunne przedstawienie przez T. Marszała wykorzystanej literatury (s. 175-186). Przemieszanie wydawnictw źródłowych z opracowaniami trudno bowiem uznać za postępowanie właściwe.

Mimo tych kilku uwag i uzupełnień, Szadkowski stownik biograficzny, jako wydawnictwo skierowane przede wszystkim do zainteresowanej historią miasta społeczności lokalnej z pewnością spełni swą ważną funkcję.

Radostaw Krajniak (Toruń) 